\title{
Mystery Case: Symptomatic isolated tongue tremor of cortical origin due to stroke
}

Smathorn Thakolwiboon, MD, Doungporn Ruthirago, MD, Pavis Laengvejkal, MD, and Henrik Wilms, MD, PhD

Neurology ${ }^{\circledR}$ 2020;94:591-592. doi:10.1212/WNL.0000000000009174

An 82-year-old right-handed man with atrial fibrillation presented with abnormal tongue movement after awakening. Neurologic examination showed tremulous tongue movements (video) without other neurologic deficit. Brain MRI showed acute infarction in the left inferolateral precentral and inferior frontal gyri (figure) without abnormality in brainstem, cerebellum, or basal ganglia. Similar to the only previously reported case of tongue tremor with right hand weakness due to stroke, tongue tremor in our case also spontaneously improved without specific treatment. ${ }^{1}$

This case provides evidence that tongue tremor can develop after sudden unilateral cortical function loss in the precentral or inferior frontal gyri.

\section{Mystery Case responses: Symptomatic isolated tongue tremor of cortical origin due to stroke}

The Mystery Case series was initiated by the Neurology ${ }^{\circledR}$ Resident \& Fellow Section to develop the clinical reasoning skills of trainees. Residency programs, medical student preceptors, and individuals were invited to use this Mystery Case as an educational tool. Responses were solicited through a group email sent to the American Academy of Neurology Consortium of Neurology Residents and Fellows and through social media.

A total of 259 participants responded to this mystery case. A large majority, $77 \%$, correctly localized the lesion to the CNS. ${ }^{1}$ Similarly, $63 \%$ correctly identified the left inferolateral precentral gyrus stroke. However, only $27 \%$ noted the left inferior frontal gyrus stroke. This is likely due to confusion with the left angular gyrus, which was the most common incorrect answer. Twenty-nine percent of respondents correctly answered that spontaneous full recovery is expected. Seven respondents answered all 3 questions correctly.

This mystery case highlights isolated tongue tremor due to stroke, which is very rare. As discussed by the authors, one other example of poststroke isolated tongue tremor has been described. ${ }^{1}$ Both the previously described patient and this patient exhibited full recovery. Isolated tongue tremor from other etiologies is also rare. Previous cases have been reported due to tumors, following gamma-knife surgery, in Wilson disease, and from neoplastic $\mathrm{Hu}$ antibodies. $^{2}$

Ariel M. Lyons-Warren, MD, PhD

Baylor College of Medicine, Texas Children's Hospital
Correspondence

Dr. Wilms

Henrik.Wilms@ttuhsc.edu

\section{MORE ONLINE}

๑ Video

$\rightarrow$ Teaching slides

links.lww.com/WNL/

B62

Survey and results

NPub.org/mc9413 


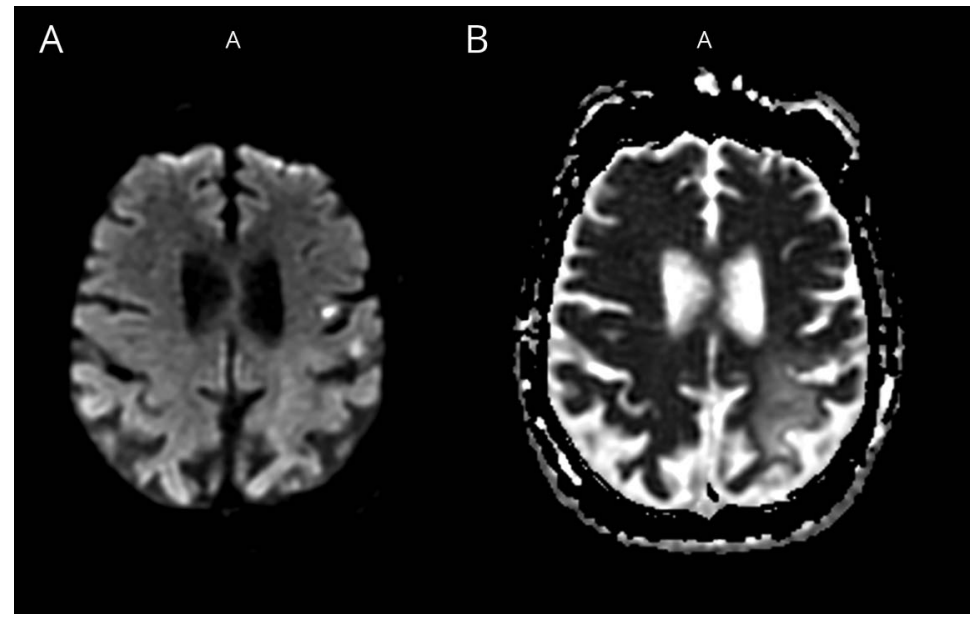

Brain MRI shows 2 hyperintensity foci on the diffusion-weighted image (A) with corresponding hypointensity area on the apparent diffusion coefficient sequences in the left inferolateral precentral and inferior frontal gyri (B). These findings are suggestive for acute infarction.

\section{Study funding}

No targeted funding reported.

\section{Disclosure}

The authors report no disclosures relevant to the manuscript. Go to Neurology.org/N for full disclosures.

Appendix Authors

\begin{tabular}{|c|c|c|c|}
\hline Name & Location & Role & Contribution \\
\hline $\begin{array}{l}\text { Smathorn } \\
\text { Thakolwiboon, } \\
\text { MD }\end{array}$ & $\begin{array}{l}\text { Texas Tech } \\
\text { University Health } \\
\text { Sciences Center, } \\
\text { Lubbock }\end{array}$ & Author & $\begin{array}{l}\text { Participated in data } \\
\text { acquisition, analysis, } \\
\text { and interpretation, } \\
\text { contributed to } \\
\text { drafting and revising } \\
\text { the manuscript for } \\
\text { intellectual content }\end{array}$ \\
\hline $\begin{array}{l}\text { Doungporn } \\
\text { Ruthirago, MD }\end{array}$ & $\begin{array}{l}\text { Massachusetts } \\
\text { General Hospital, } \\
\text { Harvard Medical } \\
\text { School, Boston }\end{array}$ & Author & $\begin{array}{l}\text { Drafting and revising } \\
\text { the manuscript for } \\
\text { intellectual content }\end{array}$ \\
\hline
\end{tabular}

\section{Appendix (continued)}

\begin{tabular}{|c|c|c|c|}
\hline Name & Location & Role & Contribution \\
\hline $\begin{array}{l}\text { Pavis } \\
\text { Laengvejkal, } \\
\text { MD }\end{array}$ & $\begin{array}{l}\text { Bumrungrad } \\
\text { International } \\
\text { Hospital, Bangkok, } \\
\text { Thailand }\end{array}$ & Author & $\begin{array}{l}\text { Critically reviewing } \\
\text { the manuscript and } \\
\text { patient care }\end{array}$ \\
\hline $\begin{array}{l}\text { Henrik Wilms, } \\
\text { MD, PhD }\end{array}$ & $\begin{array}{l}\text { Texas Tech } \\
\text { University Health } \\
\text { Sciences Center, } \\
\text { Lubbock }\end{array}$ & Author & $\begin{array}{l}\text { Design and } \\
\text { conceptualization } \\
\text { of the work, analysis } \\
\text { and interpretation } \\
\text { of data, contributed } \\
\text { to drafting and } \\
\text { revising of the } \\
\text { manuscript for } \\
\text { intellectual } \\
\text { content }\end{array}$ \\
\hline
\end{tabular}

\section{References}

1. Pandey S, Sarma N, Jain S. Tongue tremor in acute cortical infarct. Mov Disord Clin Pract 2016;3:214-215.

2. Ure RJ, Dhanju S, Lang AE, Fasano A. Unusual tremor syndromes: know in order to recognise. J Neurol Neurosurg Psychiatry 2016;87:1191-1203.

\section{Subspecialty Alerts by E-mail!}

Customize your online journal experience by signing up for e-mail alerts related to your subspecialty or area of interest. Access this free service by clicking on the "My Alerts" link on the home page. An extensive list of subspecialties, methods, and study design choices will be available for you to choose from-allowing you priority alerts to cutting-edge research in your field! 


\section{Neurology}

\section{Mystery Case: Symptomatic isolated tongue tremor of cortical origin due to stroke}

Smathorn Thakolwiboon, Doungporn Ruthirago, Pavis Laengvejkal, et al. Neurology 2020;94;591-592 Published Online before print March 18, 2020 DOI 10.1212/WNL.0000000000009174

This information is current as of March 18, 2020

$\begin{array}{ll}\begin{array}{l}\text { Updated Information \& } \\ \text { Services }\end{array} & \begin{array}{l}\text { including high resolution figures, can be found at: } \\ \text { http://n.neurology.org/content/94/13/591.full }\end{array} \\ \text { References } & \text { This article cites } 2 \text { articles, } 1 \text { of which you can access for free at: } \\ & \text { http://n.neurology.org/content/94/13/591.full\#ref-list-1 } \\ \text { Subspecialty Collections } & \text { This article, along with others on similar topics, appears in the } \\ & \text { following collection(s): } \\ & \text { Embolism } \\ \text { http://n.neurology.org/cgi/collection/embolism } & \text { Infarction } \\ & \text { http://n.neurology.org/cgi/collection/infarction } \\ & \text { Tremor } \\ \text { http://n.neurology.org/cgi/collection/tremor } & \\ & \text { Information about reproducing this article in parts (figures,tables) or in } \\ & \text { its entirety can be found online at: } \\ & \text { http://www.neurology.org/about/about_the_journal\#permissions } \\ \text { Permissions \& Licensing } & \text { Information about ordering reprints can be found online: } \\ & \text { http://n.neurology.org/subscribers/advertise }\end{array}$

Neurology ${ }^{\circledR}$ is the official journal of the American Academy of Neurology. Published continuously since 1951, it is now a weekly with 48 issues per year. Copyright @ 2020 American Academy of Neurology. All rights reserved. Print ISSN: 0028-3878. Online ISSN: 1526-632X.

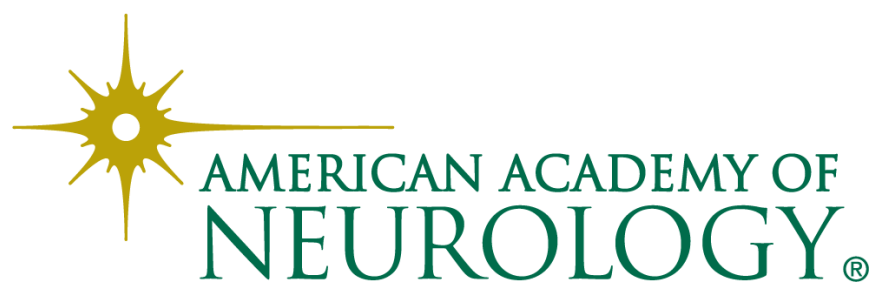

